\title{
Isoprostanoids in Clinical and Experimental Neurological Disease Models
}

\author{
Cinzia Signorini ${ }^{1, *,+}$, Claudio De Felice ${ }^{2,+}$, Jean-Marie Galano ${ }^{3}$, Camille Oger ${ }^{3}$, \\ Silvia Leoncini ${ }^{4}$, Alessio Cortelazzo ${ }^{4}$, Lucia Ciccoli ${ }^{1}$, Thierry Durand ${ }^{3}$, Joussef Hayek ${ }^{4}$ \\ and Jetty Chung-Yung Lee 5 (D) \\ 1 Department of Molecular and Developmental Medicine, University of Siena, I-53100 Siena, Italy; \\ ciccolil@yahoo.it \\ 2 Neonatal Intensive Care Unit, Azienda Ospedaliera Universitaria Senese, I-53100 Siena, Italy; \\ geniente@gmail.com \\ 3 Institut des Biomolécules Max Mousseron (IBMM), UMR 5247, Université de Montpellier, CNRS, ENSCM, \\ F-34093 Montpellier CEDEX 05, France; jean-marie.galano@umontpellier.fr (J.-M.G.); \\ camille.oger@umontpellier.fr (C.O.); thierry.durand@umontpellier.fr (T.D.) \\ 4 Child Neuropsychiatry Unit, Azienda Ospedaliera Universitaria Senese, I-53100 Siena, Italy; \\ s.leoncini74@gmail.com (S.L.); corteale@gmail.com (A.C.); j.hayek@ao-siena.toscana.it (J.H.) \\ 5 School of Biological Sciences, The University of Hong Kong, Hong Kong, China; jettylee@hku.hk \\ * Correspondence: cinzia.signorini@unisi.it \\ + These authors contributed equally to this work.
}

Received: 13 June 2018; Accepted: 9 July 2018; Published: 11 July 2018

\begin{abstract}
Isoprostanoids are a large family of compounds derived from non-enzymatic oxidation of polyunsaturated fatty acids (PUFAs). Unlike other oxidative stress biomarkers, they provide unique information on the precursor of the targeted PUFA. Although they were discovered about a quarter of century ago, the knowledge on the role of key isoprostanoids in the pathogenesis of experimental and human disease models remains limited. This is mainly due to the limited availability of highly purified molecules to be used as a reference standard in the identification of biological samples. The accurate knowledge on their biological relevance is the critical step that could be translated from some mere technical/industrial advances into a reliable biological disease marker which is helpful in deciphering the oxidative stress puzzle related to neurological disorders. Recent research indicates the value of isoprostanoids in predicting the clinical presentation and evolution of the neurological diseases. This review focuses on the relevance of isoprostanoids as mediators and potential biomarkers in neurological diseases, a heterogeneous family ranging from rare brain diseases to major health conditions that could have worldwide socioeconomic impact in the health sector. The current challenge is to identify the preferential biochemical pathways that actually follow the oxidative reactions in the neurological diseases and the consequence of the specific isoprostanes in the underlying pathogenic mechanisms.
\end{abstract}

Keywords: isoprostanes; neuroprostanes; neurological diseases; biomarkers

\section{Introduction}

Over the years, lipid peroxidation went from being a mere indicator of oxidative stress process in in vitro experimental models to become a reliable marker of oxidative damage in vivo. One major part of lipid peroxidation is the non-enzymatic/free radical process triggered by the reaction of lipids with molecular oxygen, creating initial oxidative event that is further amplified through a series of chain reactions. The chemistry of the free radical-induced lipid peroxidation chain has been thoroughly reviewed by Yin et al. [1]. Decomposed oxidized lipids (i.e., aldehydes) [2] or 
non-enzymatic oxygenated metabolites (i.e., isoprostanoids) are known as the secondary products of lipid peroxidation [3]. Isoprostanoids, which are prostaglandin isomers, are derived from polyunsaturated fatty acids (PUFAs). Unlike enzymatically produced prostaglandins, isoprostanoids are formed in situ, within the membrane, and released through hydrolysis via phospholipase $\mathrm{A}_{2}$ $\left(\mathrm{PLA}_{2}\right)[4]$.

Despite the growing interest in the product of protein gene expressions and molecular biology techniques, that are related to the complex signal transduction process, scientists should bear in mind that lipids are core components of the cell membrane in maintaining cellular structure and function.

Among the omics tools including genomics, transcriptomics, and metabolomics, lipidomics is prevalent in elucidating the pathogenesis of human diseases associated to lipids [5] and also in the development of precision medicine, which requires molecular diagnostic tests. In retrospect, the contradiction to lipidomics of isoprostanoids is influenced by cyclooxygenase-2 (COX-2) reaction products [5]. Nevertheless, isoprostanoids are investigated to identify the biological involvement and its role in the pathogenic pathways.

\section{Relevance for Lipids in Brain}

Lipids, in particular phospholipids, are involved in maintaining the functionality of neuronal cell membrane where the synaptic transmission depends on. For instance, synaptic phospholipids have been suggested as a new target for cortical hyperexcitability in psychiatric disorders [6], and synaptic lipid signaling has been shown to be involved in the glutamatergic transmission in the somatosensory cortex [7], where an alteration has been evoked in the pathophysiology of psychiatric disorder [8]. In the aging brains of healthy individuals, an association between changes in neuronal electrical excitability and the oxidation of membrane lipids appears to be related in the decline of learning and memory performance. A hypothetical explanation would lie in the fact that processes triggered by free radical and oxidant reactions on the lipid moiety would contribute to the age-related deterioration of the nervous system by damaging the phospholipids of the cell and organelle membranes. Since the peroxidized portion of the PUFAs are excised from the phospholipid by PLA 2 enzymes, it has been proposed that the balance between $\mathrm{PLA}_{2}$ and redox status would determine the rate of lipid peroxidation in the membrane and perhaps affect and deteriorate the PLA $\mathrm{A}_{2}$-dependent neuronal excitability and plasticity [9].

When searching for a biomarker related to diseases, the general trend is to attempt to identify a specific protein even though the lipid portion can be equally agreeable for the identification, especially in neurological diseases due to the high lipid content in the brain. In this regard, the relevance of lipidomics as a novel method to identify biomarkers in early detection and diagnostic criteria for Alzheimer's disease was recently reviewed [10], and furthermore, mass spectrometry-derived lipidomic profiles appeared to be different in individuals with and without cognitive impairment [11]. Therefore, complete or targeted lipidomics appears to be a relevant approach in search of biomarkers, but it is relatively unexplored when compared to the large clinical application for proteomics.

In lipid metabolism, dietary essential n-3 and n-6 polyunsaturated fatty acids (PUFAs), namely $\alpha$-linolenic acid (ALA, 18:3n-3) and linoleic acid (LA, 18:2n-6), play crucial roles in maintaining tissue levels [12]. However, docosahexaenoic acid (DHA; 22:6, n-3), and arachidonic acid (AA; 20:4, $\mathrm{n}-6)$, from the diet are more important PUFAs as they are abundant in the brain and vital components of the neuronal phospholipids. Further, in n-6 PUFA metabolism, adrenic acid (AdA; 22:4, n-6) is produced by elongation of AA and concentrated in the myelin sheath within the brain white matter of the primates. PUFAs are esterified in situ to phospholipids and in particular, DHA, AA, and AdA (Figure 1) are crucial components of neuronal or glia phospholipids.

PUFAs are related to the physiological developmental of the neurological system in the brain when considering the pathogenesis related to neuroplasticity, neurogenesis, and synaptogenesis [13]. In relation, nutritional n-3 PUFAs deficiency, especially during the perinatal period, alters neuronal plasticity [14]. Moreover, it is suggested that a good balance of $n-3 / n-6$ PUFA ratio protects the 
cognitive deficits induced by neuroinflammation [15], and furthermore enrichment of n-3 PUFAs mediate mechanisms involved in learning memory performance [16].

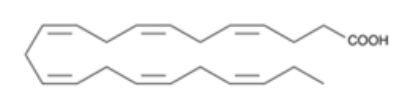

Docosahexaenoic Acid (22:6, n-3)

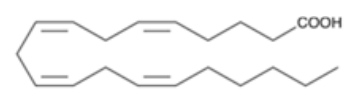

Arachidonic Acid (20:4, n-6)

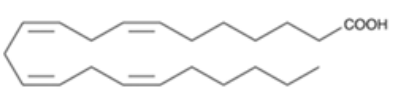

Adrenic Acid (22:4, n-6)

Figure 1. Chemical structures of key polyunsaturated fatty acids related to neuronal phospholipids.

As shown in the brain of rodents, DHA and AA distribution is region-specific and needed for brain function and development [17]. In particular, DHA promotes neuroplasticity, neurogenesis, synaptogenesis and neuroimmune interactions $[18,19]$. In a recent report, enriched brain levels of DHA by genetic conversion of n-6 PUFA to n-3-PUFA led to increased hippocampal neurogenesis [20]. Neurogenesis was also increased in the hippocampus of aged rats supplemented with DHA [19]. On the other hand, Coti Bertrand et al., demonstrated that neurogenesis was decreased in brain of DHA-deficient embryonic rat [21].

\section{Relevance of Lipid Peroxidation Products in Neurodegeneration}

In brain, lipid peroxidation products, namely malondialdehyde (MDA), protein-bound acrolein adduct, and isoprostanoids, are reported to be elevated in the progression of Alzheimer's disease (AD) from the earliest to the late stages and were also detected in mild cognitive impairment (MCI) conditions [22]. As a result, these products are currently suggested to contribute to neurodegeneration. In addition, immunochemical detection of lipid hydroperoxide- and aldehyde-modified proteins, and selective protein targets of aldehydes were found in AD [23,24]. Nevertheless, relationships between lipid peroxidation products and key clinical AD features remain to be confirmed.

Of note in this review is the uniqueness of isoprostanoids in neurodegeneration. Through interaction of radical species, such as radical oxygen species (ROS), PUFAs undergo a series of non-enzymatic lipid peroxidation and generate specialized lipid mediators such as $\mathrm{F}_{2}$-isoprostanes $\left(\mathrm{F}_{2}\right.$-IsoPs), $\mathrm{F}_{2}$-dihomo-isoprostanes ( $\mathrm{F}_{2}$-dihomo-IsoPs), and $\mathrm{F}_{4}$-neuroprostanes $\left(\mathrm{F}_{4}\right.$-NeuroPs $)$ from $\mathrm{AA}, \mathrm{AdA}$, and DHA, respectively. Among all the isoprostanoids identified so far, the chemical structures related closest to neurological diseases [25-28] are reported in Figure 2.

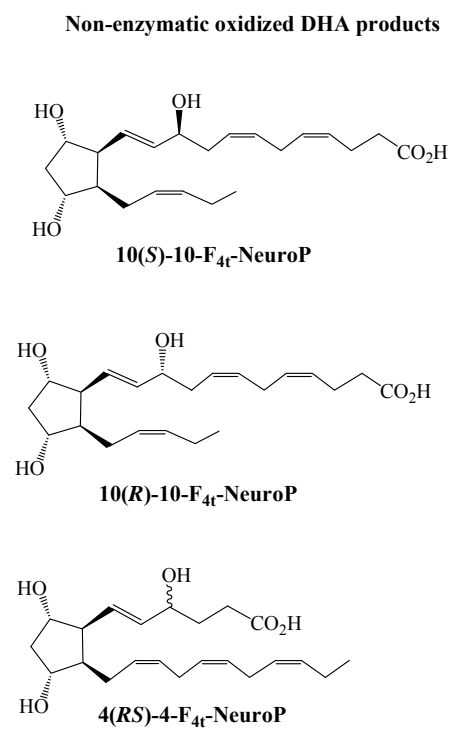

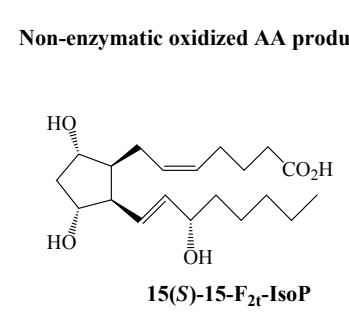

Non-enzymatic oxidized AdA products
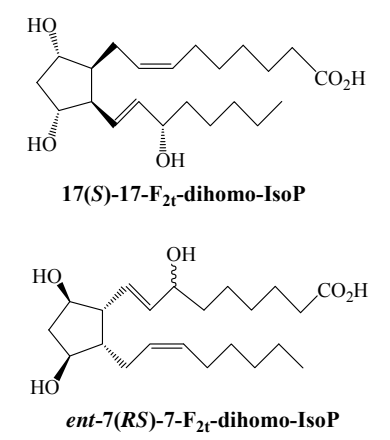

Figure 2. Chemical structures related to oxidized products of docosahexaenoic acid (DHA), arachidonic acid (AA), and adrenic acid (AdA). Legend: IsoP: isoprostane; NeuroP: neuroprostane. 
The result of cyclization process in AA oxidation forms four series comprising of 5-, 8-, 12-, and $15-\mathrm{F}_{2}$-Isoprostanes (IsoP). $\mathrm{F}_{2}$-IsoPs have been defined as the gold standard marker of lipid peroxidation in vivo for their relevance in several human diseases, including neurodegenerative disease $[29,30]$.

Moreover, AdA oxidation form four series of regioisomers (7-, 10-, 14-, and 17-series) [31], and were detected in AD patients [31,32], and also in Rett syndrome (RTT) [25], Down syndrome [33], and epileptic [34] patients. The myelin sheath is concentrated with $\mathrm{AdA}$ and $\mathrm{F}_{2}$-dihomo-IsoPs have been suggested to be specific in assessing the extent of free radical damage of the myelin [31]. Likewise, $\mathrm{F}_{4}$-NeuroPs measurements are relatively specific to oxidative damage of the neuronal membranes due to abundant DHA in the brain gray matter [35,36]. In this regard, $\mathrm{F}_{4}-\mathrm{NeuroPs}$, and not $\mathrm{F}_{2}$-IsoPs, were proposed to be the critical group of oxidized DHA products for neuronal damage [37-39]. $\mathrm{F}_{2}$-IsoPs and $\mathrm{F}_{4}$-NeuroPs were also investigated as biomarkers to explore the role of the oxidative damage in the pathogenesis of Parkinson's disease [28]. In such neurological conditions, plasma levels of $\mathrm{F}_{2}$-IsoPs and $\mathrm{F}_{4}$-NeuroPs provided evidence that peripheral indices of oxidative damage are elevated at different stages of the disease [28].

Non-enzymatic DHA oxidation generates eight regioisomer series (4-, 7-, 10-, 11-, 13-, 14-, 17- or 20-series). Among all the $\mathrm{F}_{4}$-NeuroP molecules, a few isomers were characterized in neuro-pathological conditions, and so far, $4-\mathrm{F}_{4 \mathrm{t}}-\mathrm{NeuroPs}$ and $10-\mathrm{F}_{4 \mathrm{t}}-\mathrm{NeuroPs}$ are the most represented $[3,27,34,40]$. Since 1999, $\mathrm{F}_{4}$-NeuroPs have been investigated as specific marker of DHA peroxidation in AD [41], and the interest in such matter is continuing [42]. Notably, the debate on the use of nutraceutical intervention specifically, DHA supplementation is ongoing. In this regard, PUFAs and DHA levels are reported to be associated to reduced risk of AD. Nevertheless, lipid peroxidation products of n-3-PUFA have been associated to increased levels of $\beta$-amyloid peptide in in vitro studies [43], indicating that biological activities are stimulated by oxidized DHA and should be asserted in nutrition related studies. Considering this, caution must also be made in scientific experimentations as PUFAs are prone to oxidation in in vitro, whereas supplementation of PUFA reduce in vivo oxidative stress by lowering $\mathrm{F}_{2}$-IsoPs levels $[44,45]$; the two outcomes may not be complementary.

Overall, PUFAs and their oxygenated metabolites of non-enzymatic lipid peroxidation have been investigated as potential biomarkers and/or therapeutic target in different neurological diseases. The measurement of $\mathrm{F}_{2}$-IsoPs can be accurately carried out in all body fluids by mass spectrometric analyses [46,47]. Currently, such detections are performed to evaluate the occurrence of lipid peroxidation events in numerous diseases including neurodegenerative diseases [48-50]. Nevertheless, it has been focused on the possibility that single $\mathrm{F}_{2}$-IsoPs measurements could represent "spot" measurements of lipid peroxidation process rather than understanding the real biological role of the isoprostanoids [51]. As a biomarker, detection of different isomers and/or metabolites [29] and repeated measurements over time of such oxidized lipid products should be carried out to reinforce and validate for their role as biomarkers. Such assessment so far has been executed in Rett (RTT) syndrome where marked increased levels of isoprostanoids have been detected in typical RTT at every clinical stages of the disease [52].

\section{Mechanisms Underlying Different Brain Diseases: Similar but Not the Same}

Isoprostanoids, mainly $\mathrm{F}_{2}$-IsoPs, have been detected to be elevated in different neurological diseases from distinct etiological causes [36,53-55]. Due to the broad and general understanding of the isoprostanoids, they are repeatedly neglected for its specificity and often considered nonspecific indicators of oxidative damage. Nevertheless, $\mathrm{F}_{2}$-IsoP formation appeared to be modulated by specific mechanisms in the neurological diseases arising from methyl-CpG binding protein 2 (MECP2) gene expression, the so-called MECP2-pathies [56].

Isoprostanoid formation appears to be intimately linked to disorders of neurodevelopmental caused by alterations in the methyl-CpG binding protein 2 (MECP2) gene expression. In neurodevelopmental disorders, it is linked to under-or over-expression of $M E C P 2$ gene, such as in RTT and MECP2 
duplication syndrome (MDS), where isoprostanoids formation have been shown to be specifically related to different $M E C P 2$ gene mutations [25,26,52,57-59] (Table 1).

Moreover, in symptomatic RTT mice (Mecp2 stop/y model), the amounts of 4- $\mathrm{F}_{4 \mathrm{t}}-\mathrm{NeuroP}$ and $10-\mathrm{F}_{4 \mathrm{t}}$-NeuroP in brain tissue have been shown to be significantly higher than the wild-type, and highly correlated to the phenotypic severity [27].

Table 1. Isoprostanoids formation is related to altered MECP2 gene expression.

\begin{tabular}{|c|c|c|c|}
\hline \multirow[t]{2}{*}{$\begin{array}{l}\text { Neurodevelopmental Disorders Caused by } \\
\text { Alteration in the } M E C P 2 \text { Gene Expression }\end{array}$} & \multicolumn{3}{|c|}{ Isoprostanoids } \\
\hline & Plasma free & Plasma free & Plasma free \\
\hline & $\mathrm{F}_{2}$-IsoPs & $\mathrm{F}_{4}$-NeuroPs & $\mathrm{F}_{2}$-dihomoIsoPs \\
\hline Rett Syndrome (RTT) & $+a$ & $+b$ & $+c$ \\
\hline \multicolumn{4}{|l|}{ Most frequent $M E C P 2$ mutations in RTT: } \\
\hline R106W & $\leftrightarrow^{\mathrm{b}}$ & $\leftrightarrow^{\mathrm{b}}$ & \\
\hline R $133 \mathrm{C}$ & $\leftrightarrow \mathrm{b}$ & $\leftrightarrow^{\mathrm{b}}$ & \\
\hline $\mathrm{T} 158 \mathrm{M}$ & $+++\mathrm{b}$ & $\leftrightarrow^{\mathrm{b}}$ & \\
\hline $\mathrm{R} 168 \mathrm{X}$ & $+++\mathrm{b}$ & $+++b$ & \\
\hline $\mathrm{R} 255 \mathrm{X}$ & $+++b$ & $+++b$ & \\
\hline $\mathrm{R} 270 \mathrm{X}$ & $+++\mathrm{b}$ & $++b$ & \\
\hline $\mathrm{R} 294 \mathrm{X}$ & $\leftrightarrow^{\mathrm{b}}$ & $\leftrightarrow^{\mathrm{b}}$ & \\
\hline R306X & $\leftrightarrow^{\mathrm{b}}$ & $\leftrightarrow^{\mathrm{b}}$ & \\
\hline C-terminal deletions & $\leftrightarrow^{\mathrm{b}}$ & $\leftrightarrow^{\mathrm{b}}$ & \\
\hline Large deletions & $\leftrightarrow^{\mathrm{b}}$ & $++b$ & \\
\hline$M E C P 2$ duplication syndrome (MDS) & $++\mathrm{d}$ & $++d$ & $\leftrightarrow^{\mathrm{d}}$ \\
\hline
\end{tabular}

Legend: $\leftrightarrow$, not significantly different as compared to control subjects;,+++ and +++ , increased highly increased and very highly increased, respectively, as compared to control subjects; C TER D, C terminal deletion; L DEL,

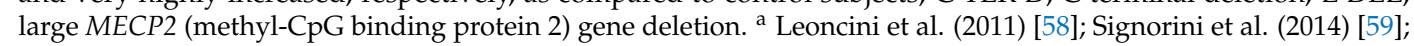

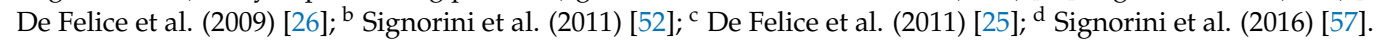

RTT, which is due to de novo mutations in MECP2 gene, features transient autistic-like phase [60] and has been recognized as model of neurodevelopmental disorders [61]. However, RTT is a progressive neurological disorder and not degenerative. Considering this, it is conceivable that various progressive neurological conditions, even on a degenerative basis, may share similar oxidative mechanisms. Usually, such common mechanisms involve the formation of isoprostanoids, albeit with their own specificity. Indeed, not only the products of the non-enzymatic lipid peroxidation but also the oxidation pathways were found to be relevant in previous studies (Table 1). By identifying the isomers that are synthesized in different oxidation pathways of the PUFA, one is able to (i) understand the time course of disease mechanisms, (ii) identify molecular targets (i.e., therapeutic target), and (iii) know the relationship with the clinical manifestations. Therefore, the availability of chemically synthesized molecules is crucial to test the clinical relevance of non-enzymatic oxidized products of PUFA.

\section{In Search of a Biomarker: Isoprostanoids as Biomarkers in Neurological Diseases}

Unlike other oxidative stress biomarkers, isoprostanoids provide unique information on the precursor and/or the targeted PUFA. Accordingly, isoprostanoid formation identifies which PUFA precursor is affected by the non-enzymatic oxidative process. Thus, $\mathrm{F}_{2}-\mathrm{IsoP}, \mathrm{F}_{4}$-NeuroP, and $\mathrm{F}_{2}$-dihomoIsoP levels are not only specific indices of oxidative stress but also markers of biological oxidative damage involving specific PUFAs.

According to the criteria for an ideal biomarker, it should be quantifiable to characterize a biological process and to predict clinical results, even after diet or drug intervention [62]. In particular, an ideal biomarker of oxidative damage (i) should detect a major part of total ongoing oxidative damage in vivo, (ii) should be measured employing robust technology, (iii) should not be confounded by diet, and (iv) should be stable on storage [63]. Indeed, several studies showed isoprostanoids do meet such criteria for neurological diseases [25,28,38,52]. Previous studies tested the non-enzymatic 
oxygenated metabolites of lipid peroxidation (i) in different pathologies [27,57,64], (ii) in groups of subjects at different ages [25], (iii) in relation to the severity of the disease [52,58], (iv) in relation to the pre-symptomatic clinical status of the disease [38], (v) in animal models [38], and (vi) in relation to drug treatment/supplementation [65].

In view of biomarkers as useful tools to identify targeted therapeutic treatment and drug development processes, knowledge of the molecular precursors of isoprostanoids has led to the experimentation of n-3 PUFAs supplementation in RTT. In subject treated with what specifically, a significant decrease in the non-enzymatic oxygenated metabolites of lipid peroxidation was observed, and a clinical improvement was found [52,59,65]. In these investigations $[52,59,65], n-3$ PUFA supplementation was not merely considered as a simple antioxidant treatment or a component in generic antioxidant defense; rather these studies interpreted n-3 PUFAs as biomolecules enriched in the brain lipids to prevent degeneration of the pathophysiological processes of the disease.

When considering the outcome of neural related diseases, it is crucial to consider the method of measurement as it needs to be sensitive enough for detection in order to avoid misinterpretation of data from rare samples. Currently, measurements of isoprostanoids in biological samples are widely carried out by mass spectrometry (MS), singly or tandem (MS/MS) such as gas chromatography-mass spectrometry (GC-MS), GC-MS/MS, liquid chromatography-mass spectrometry (LC-MS), and LC-MS/MS [66]. These accredited techniques for isoprostanoid determination in biological samples have advantages and disadvantages. Although identifications of the investigated molecules are specific and sensitive at low quantities (i.e., in the order of the picograms), it can be costly and time consuming. Furthermore, isoprostanoids are composed of numerous types of isomers due to hydrogen abstraction and molecular oxygen addition in the PUFA oxidation process, therefore it is necessary to unravel the molecular rearrangement of oxidized PUFA products mainly derived from AA, DHA, and AdA [31,67,68] that are richly found in the neurons.

The available scientific literature on $\mathrm{F}_{4}$-NeuroP and $\mathrm{F}_{2}$-dihomo-IsoP remains limited. This is mainly due to the limited availability of purified molecules to be used as reference compounds in the identification of isoprostanoids in biological samples, which is an indispensable step in the exploration of the cause-effect relationship between the neurological damage and the levels of isoprostanoids in the bloodstream or in other fluids and tissues. Nevertheless, assays performed in plasma or urine samples are proving useful to predict clinical presentation/evolution of neurological diseases $[25,27,31-34,38,52,57,59,69,70]$ (Table 2). Plasma 10- $\mathrm{F}_{4 \mathrm{t}}-\mathrm{NeuroP}$ and $4-\mathrm{F}_{4 \mathrm{t}}-\mathrm{NeuroP}$ levels were shown to be useful to discriminate between different brain diseases and the association to clinical severity appeared to be distinctive for different neurological conditions, thus suggesting that in vivo DHA oxidation follows preferential chemical rearrangements according to different human brain diseases. Consequently, the abundance of plasma $4-\mathrm{F}_{4 \mathrm{t}}-\mathrm{NeuroP}$ and $10-\mathrm{F}_{4 \mathrm{t}}-\mathrm{NeuroP}$ is able to predict disease severity (Table 3). 
Table 2. $\mathrm{F}_{4}$-NeuroP and $\mathrm{F}_{2}$-dihomo-IsoP detection in different human and experimental brain disease models.

\begin{tabular}{|c|c|c|c|c|}
\hline Human and Experimental Brain Disease Models & Sample & PUFA Non-Enzymatic Oxidized Products & Methodology & References \\
\hline \multicolumn{5}{|l|}{ Human Brain Disease } \\
\hline Alzheimer's Disease & $\begin{array}{l}\text { urine } \\
\text { brain }\end{array}$ & $\begin{array}{l}\mathrm{F}_{2} \text {-IsoPs, } \mathrm{F}_{2} \text {-dihomo-IsoPs, } \mathrm{F}_{4} \text {-NeuroPs } \\
\mathrm{F}_{2} \text {-IsoPs, } \mathrm{F}_{2} \text {-dihomo-IsoPs, } \mathrm{F}_{4} \text {-NeuroPs }\end{array}$ & $\begin{array}{l}\text { LC-MS/MS } \\
\text { GC-MS }\end{array}$ & $\begin{array}{l}\text { García-Blanco et al. (2018) [32] } \\
\text { VanRollins et al. (2008) [31] }\end{array}$ \\
\hline $\begin{array}{l}\text { Multiple sclerosis, Autism spectrum disorders, } \\
\text { Rett syndrome, Down syndrome }\end{array}$ & plasma & $4(\mathrm{RS})-4-\mathrm{F}_{4 \mathrm{t}}-\mathrm{NeuroP}$ and $10(\mathrm{RS})-10-\mathrm{F}_{4 \mathrm{t}}-\mathrm{NeuroP}$ & GC-MS/MS & Signorini et al. (2018) [27] \\
\hline Down syndrome & plasma & $\begin{array}{c}\mathrm{F}_{2} \text {-IsoPs, } \mathrm{F}_{2} \text {-dihomo-IsoPs, } \mathrm{F}_{4} \text {-NeuroPs } \\
\text { 4(RS)-4- } \mathrm{F}_{4 \mathrm{t}} \text {-NeuroP, } 10 \text {-epi-10-- } \text { Ft }_{4 \mathrm{t}} \text {-NeuroP, }\end{array}$ & GC-MS/MS & Manna et al. (2016) [33] \\
\hline Epilepsy & urine & 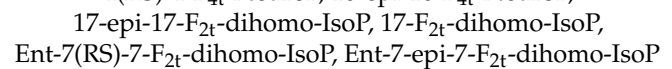 & HPLC-MS/MS & Medina et al. (2015) [34] \\
\hline Traumatic brain injury & cerebrospinal fluid & Isofurans, $\mathrm{F}_{4}$-NeuroPs, $\mathrm{F}_{2}$-IsoPs & GC-MS & Corcoran et al. (2011) [70] \\
\hline$M E C P 2$ duplication syndrome & plasma & $\mathrm{F}_{4}$-NeuroPs & GC-MS/MS & Signorini et al. (2016) [57] \\
\hline Experimental Brain Disease & & & & \\
\hline Perinatal hypoxic-ischemic damage & brain & $\mathrm{F}_{4}$-NeuroPs, neurofurans, $\mathrm{F}_{2}$-dihomo-IsoPs & LC-MS & Solberg et al. (2017) [69] \\
\hline Rett syndrome & $\begin{array}{l}\text { plasma } \\
\text { brain }\end{array}$ & $\begin{array}{c}\text { 4(RS)-4- } \mathrm{F}_{4 \mathrm{t}}-\text { NeuroP and } 10(\mathrm{RS})-10-\mathrm{F}_{4 \mathrm{t}}-\text { NeuroP } \\
\mathrm{F}_{4} \text {-NeuroPs, } \mathrm{F}_{2} \text {-IsoPs }\end{array}$ & GC-MS/MS & $\begin{array}{l}\text { Signorini et al. (2018) [27] } \\
\text { De Felice et al. (2014) [38] }\end{array}$ \\
\hline
\end{tabular}

gas chromatography-tandem mass spectrometry; LC-MS/MS, liquid chromatography-tandem mass spectrometry; PUFA: polyunsaturated fatty acid. 
Table 3. Plasma 4(RS)-4-F $4 \mathrm{t}-\mathrm{NeuroP}$ and $10(\mathrm{RS})-10-\mathrm{F}_{4 \mathrm{t}}-\mathrm{NeuroP}$ abundancy and disease severity.

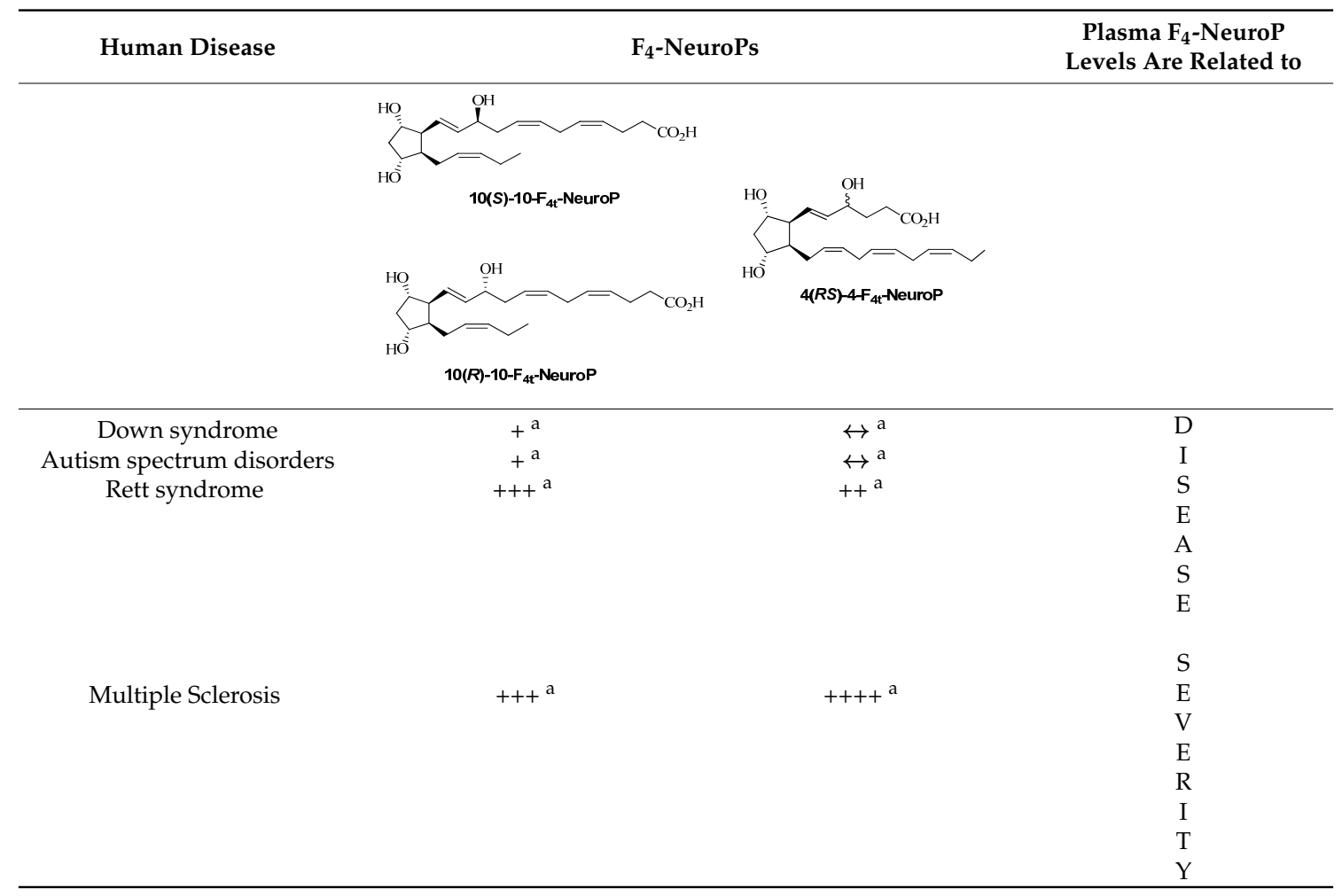

Legend: $\leftrightarrow$, not significantly different as compared to control subjects;,,++++++ , and ++++ , increased, highly increased, very highly increased, and extremely increased respectively, as compared to control subjects. a Signorini et al. (2018) [27].

\section{Conclusions and Future Research}

Although they are known about a quarter of century ago, the knowledge on the key role of isoprostanoids in the pathogenesis of experimental model and human diseases remain limited. Here, we summarized the current evidence on the role of isoprostanoids in the clinical presentation and evolution of several neurological diseases, ranging from very rare brain diseases to major health conditions taking into the account of worldwide socioeconomic impact (Figure 3). The current challenge is to identify the preferential biochemical pathways that actually follow oxidative reactions in the biological systems and, consequently, the identification of the specific isoprostane isomers related to the underlying pathogenic mechanism. It is clear that the accurate knowledge on the biological relevance of these molecules is the critical step that could be translated as technical/industrial advances of reliable biological disease markers and potentially aid in predicting the clinical progression and deciphering in the oxidative stress puzzle related to neurological disorders. 


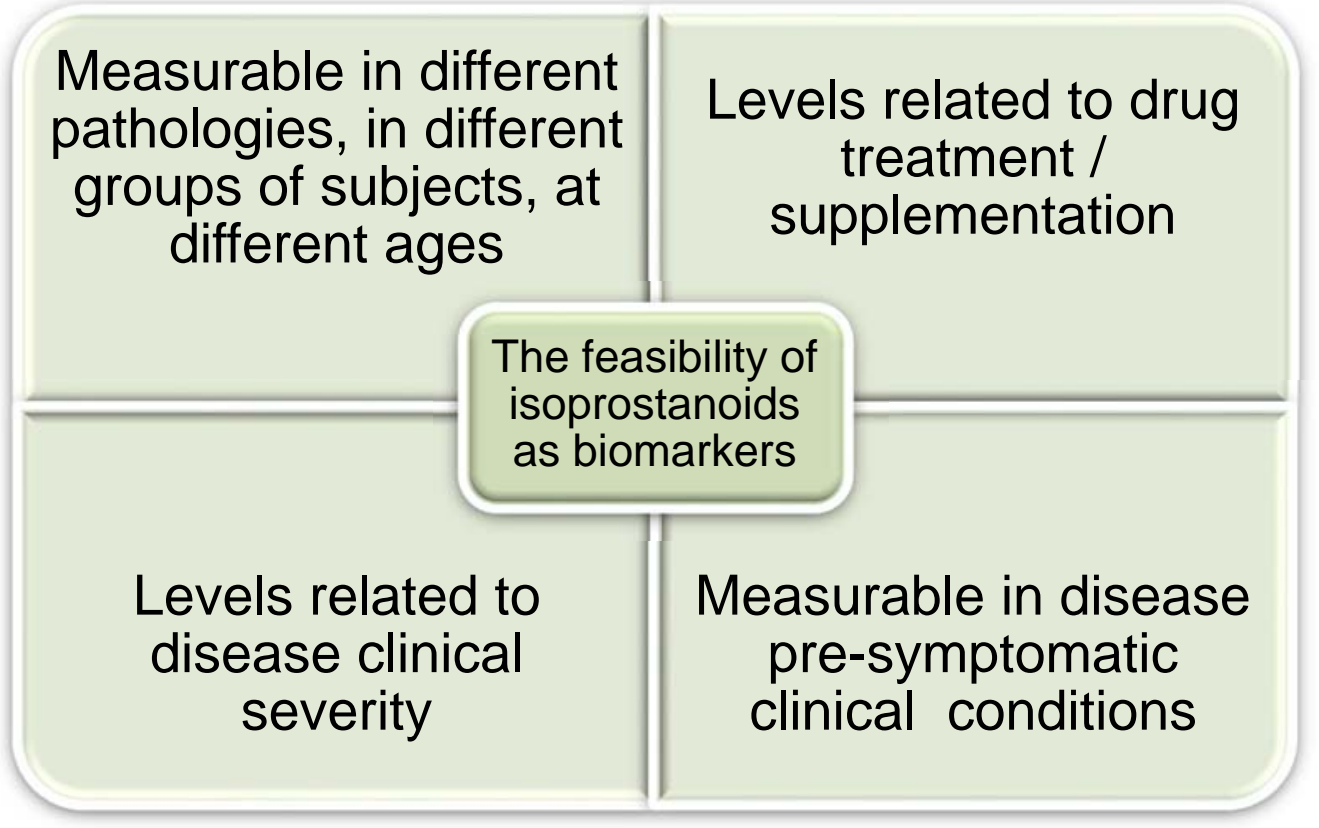

Figure 3. Characteristics that make isoprostanoids potentially useful biomarkers.

Author Contributions: C.S., C.D.F., J.C.-Y.L., and T.D. developed the project idea; C.S. and C.D.F. wrote the first draft of the manuscript; C.S., C.D.F., J.-M.G., C.O., S.L., A.C., L.C., J.C.-Y.L., J.H., and T.D. conducted the literature review and revised the manuscript.

Funding: This research received no external funding.

Acknowledgments: The authors would like to dedicate this review in memory of Mario Comporti (Siena 1935-2014), international pioneer in the exploration of oxidative stress in disease. The authors received no specific funding for this work.

Conflicts of Interest: The authors declare no conflict of interest.

\section{References}

1. Yin, H.; Xu, L.; Porter, N.A. Free radical lipid peroxidation: Mechanisms and analysis. Chem. Rev. 2011, 111, 5944-5972. [CrossRef] [PubMed]

2. Sousa, B.C.; Pitt, A.R.; Spickett, C.M. Chemistry and analysis of HNE and other prominent carbonyl-containing lipid oxidation compounds. Free Radic. Biol. Med. 2017, 111, 294-308. [CrossRef] [PubMed]

3. Galano, J.M.; Lee, Y.Y.; Oger, C.; Vigor, C.; Vercauteren, J.; Durand, T.; Giera, M.; Lee, J.C. Isoprostanes, neuroprostanes and phytoprostanes: An overview of 25 years of research in chemistry and biology. Prog. Lipid Res. 2017, 68, 83-108. [CrossRef] [PubMed]

4. Morrow, J.D.; Awad, J.A.; Boss, H.J.; Blair, I.A.; Roberts, L.J., 2nd. Non-cyclooxygenase-derived prostanoids (F2-isoprostanes) are formed in situ on phospholipids. Proc. Natl. Acad. Sci. USA 1992, 89, 10721-10725. [CrossRef] [PubMed]

5. Gross, R.W. The evolution of lipidomics through space and time. Biochim. Biophys. Acta 2017, 1862, 731-739. [CrossRef] [PubMed]

6. Thalman, C.; Horta, G.; Qiao, L.; Endle, H.; Tegeder, I.; Cheng, H.; Laube, G.; Sigrudsson, T.; Hauser, M.J.; Tenzer, S.; et al. Synaptic phospholipids as a new target for cortical hyperexcitability and E/I balance in psychiatric disorders. Mol. Psychiatry 2018. [CrossRef] [PubMed]

7. Unichenko, P.; Kirischuk, S.; Yang, J.W.; Baumgart, J.; Roskoden, T.; Schneider, P.; Sommer, A.; Horta, G.; Radyushkin, K.; Nitsch, R.; et al. Plasticity-Related Gene 1 Affects Mouse Barrel Cortex Function via Strengthening of Glutamatergic Thalamocortical Transmission. Cereb. Cortex 2016, 26, 3260-3672. [CrossRef] [PubMed] 
8. Trimbuch, T.; Beed, P.; Vogt, J.; Schuchmann, S.; Maier, N.; Kintscher, M.; Breustedt, J.; Schuelke, M.; Streu, N.; Kieselmann, O.; et al. Synaptic PRG-1 modulates excitatory transmission via lipid phosphate-mediated signaling. Cell 2009, 138, 1222-1235. [CrossRef] [PubMed]

9. Hermann, P.M.; Watson, S.N.; Wildering, W.C. Phospholipase $\mathrm{A}_{2}-\mathrm{Nexus}$ of aging, oxidative stress, neuronal excitability, and functional decline of the aging nervous system? Insights from a snail model system of neuronal aging and age-associated memory impairment. Front. Genet. 2014, 5, 419. [CrossRef] [PubMed]

10. Wong, M.W.; Braidy, N.; Poljak, A.; Sachdev, P.S. The application of lipidomics to biomarker research and pathomechanisms in Alzheimer's disease. Curr. Opin. Psychiatry 2017, 30, 136-144. [CrossRef] [PubMed]

11. Barbash, S.; Garfinkel, B.P.; Maoz, R.; Simchovitz, A.; Nadorp, B.; Guffanti, A.; Bennett, E.R.; Nadeau, C.; Türk, A.; Paul, L.; et al. Alzheimer's brains show inter-related changes in RNA and lipid metabolism. Neurobiol. Dis. 2017, 106, 1-13. [CrossRef] [PubMed]

12. Saini, R.K.; Keum, Y.S. Omega-3 and omega-6 polyunsaturated fatty acids: Dietary sources, metabolism, and significance-A review. Life Sci. 2018, 203, 255-267. [CrossRef] [PubMed]

13. Howsmon, D.P.; Adams, J.B.; Kruger, U.; Geis, E.; Gehn, E.; Hahn, J. Erythrocyte fatty acid profiles in children are not predictive of autism spectrum disorder status: A case control study. Biomark. Res. 2018, 6, 12. [CrossRef] [PubMed]

14. Madore, C.; Nadjar, A.; Delpech, J.C.; Sere, A.; Aubert, A.; Portal, C.; Joffre, C.; Layé, S. Nutritional n-3 PUFAs deficiency during perinatal periods alters brain innate immune system and neuronal plasticity-associated genes. Brain Behav. Immun. 2014, 41, 22-31. [CrossRef] [PubMed]

15. Delpech, J.C.; Madore, C.; Joffre, C.; Aubert, A.; Kang, J.X.; Nadjar, A.; Layé, S. Transgenic increase in n-3/n-6 fatty acid ratio protects against cognitive deficits induced by an immune challenge through decrease of neuroinflammation. Neuropsychopharmacology 2015, 40, 525-536. [CrossRef] [PubMed]

16. Su, H.M. Mechanisms of n-3 fatty acid-mediated development and maintenance of learning memory performance. J. Nutr. Biochem. 2010, 21, 364-373. [CrossRef] [PubMed]

17. Xiao, Y.; Huang, Y.; Chen, Z.Y. Distribution, depletion and recovery of docosahexaenoic acid are region-specific in rat brain. Br. J. Nutr. 2005, 94, 544-550. [CrossRef] [PubMed]

18. Dinel, A.L.; Rey, C.; Bonhomme, C.; Le Ruyet, P.; Joffre, C.; Layé, S. Dairy fat blend improves brain DHA and neuroplasticity and regulates corticosterone in mice. Prostagland. Leuk. Essent. Fat. Acids 2016, 109, 29-38. [CrossRef] [PubMed]

19. Kawakita, E.; Hashimoto, M.; Shido, O. Docosahexaenoic acid promotes neurogenesis in vitro and in vivo. Neuroscience 2006, 139, 991-997. [CrossRef] [PubMed]

20. Kang, J.X.; Gleason, E.D. Omega-3 Fatty acids and hippocampal neurogenesis in depression. CNS Neurol. Disord. Drug Targets 2013, 12, 460-465. [CrossRef] [PubMed]

21. Coti Bertrand, P.; O'Kusky, J.R.; Innis, S.M. Maternal dietary (n-3) fatty acid deficiency alters neurogenesis in the embryonic rat brain. J. Nutr. 2006, 136, 1570-1575. [CrossRef] [PubMed]

22. Bradley-Whitman, M.A.; Lovell, M.A. Biomarkers of lipid peroxidation in Alzheimer disease (AD): An update. Arch. Toxicol. 2015, 89, 1035-1044. [CrossRef] [PubMed]

23. Sugiyama, A.; Sun, J. Immunochemical detection of lipid hydroperoxide- and aldehyde-modified proteins in diseases. Subcell. Biochem. 2014, 77, 115-125. [CrossRef] [PubMed]

24. Sultana, R.; Perluigi, M.; Allan Butterfield, D. Lipid peroxidation triggers neurodegeneration: A redox proteomics view into the Alzheimer disease brain. Free Radic. Biol. Med. 2013, 62, 157-169. [CrossRef] [PubMed]

25. De Felice, C.; Signorini, C.; Durand, T.; Oger, C.; Guy, A.; Bultel-Poncé, V.; Galano, J.M.; Ciccoli, L.; Leoncini, S.; D'Esposito, M.; et al. $\mathrm{F}_{2}$-dihomo-isoprostanes as potential early biomarkers of lipid oxidative damage in Rett syndrome. J. Lipid Res. 2011, 52, 2287-2297. [CrossRef] [PubMed]

26. De Felice, C.; Ciccoli, L.; Leoncini, S.; Signorini, C.; Rossi, M.; Vannuccini, L.; Guazzi, G.; Latini, G.; Comporti, M.; Valacchi, G.; et al. Systemic oxidative stress in classic Rett syndrome. Free Radic. Biol. Med. 2009, 47, 440-448. [CrossRef] [PubMed]

27. Signorini, C.; De Felice, C.; Durand, T.; Galano, J.M.; Oger, C.; Leoncini, S.; Ciccoli, L.; Carone, M.; Ulivelli, M.; Manna, C.; et al. Relevance of 4-F(4t)-neuroprostane and 10-F(4t)-neuroprostane to neurological diseases. Free Radic. Biol. Med. 2018, 115, 278-287. [CrossRef] [PubMed] 
28. Seet, R.C.; Lee, C.Y.; Lim, E.C.; Tan, J.J.; Quek, A.M.; Chong, W.L.; Looi, W.F.; Huang, S.H.; Wang, H.; Chan, Y.H.; et al. Oxidative damage in Parkinson disease: Measurement using accurate biomarkers. Free Radic. Biol. Med. 2010, 48, 560-566. [CrossRef] [PubMed]

29. Galano, J.M.; Lee, Y.Y.; Durand, T.; Lee, J.C. Special Issue on "Analytical Methods for Oxidized Biomolecules and Antioxidants". The use of isoprostanoids as biomarkers of oxidative damage, and their role in human dietary intervention studies. Free Radic. Res. 2015, 49, 583-598. [CrossRef] [PubMed]

30. Musiek, E.S.; Yin, H.; Milne, G.L.; Morrow, J.D. Recent advances in the biochemistry and clinical relevance of the isoprostane pathway. Lipids 2005, 40, 987-994. [CrossRef] [PubMed]

31. VanRollins, M.; Woltjer, R.L.; Yin, H.; Morrow, J.D.; Montine, T.J. $F_{2}$-dihomo-isoprostanes arise from free radical attack on adrenic acid. J. Lipid Res. 2008, 49, 995-1005. [CrossRef] [PubMed]

32. García-Blanco, A.; Peña-Bautista, C.; Oger, C.; Vigor, C.; Galano, J.M.; Durand, T.; Martín-Ibáñez, N.; Baquero, M.; Vento, M.; Cháfer-Pericás, C. Reliable determination of new lipid peroxidation compounds as potential early Alzheimer Disease biomarkers. Talanta 2018, 184, 193-201. [CrossRef] [PubMed]

33. Manna, C.; Officioso, A.; Trojsi, F.; Tedeschi, G.; Leoncini, S.; Signorini, C.; Ciccoli, L.; De Felice, C. Increased non-protein bound iron in Down syndrome: Contribution to lipid peroxidation and cognitive decline. Free Radic. Res. 2016, 50, 1422-1431. [CrossRef] [PubMed]

34. Medina, S.; Miguel-Elízaga, I.D.; Oger, C.; Galano, J.M.; Durand, T.; Martínez-Villanueva, M.; Castillo, M.L.; Villegas-Martínez, I.; Ferreres, F.; Martínez-Hernández, P.; et al. Dihomo-isoprostanes-nonenzymatic metabolites of AdA-are higher in epileptic patients compared to healthy individuals by a new ultrahigh pressure liquid chromatography-triple quadrupole-tandem mass spectrometry method. Free Radic. Biol. Med. 2015, 79, 154-163. [CrossRef] [PubMed]

35. Greco, A.; Minghetti, L. Isoprostanes as biomarkers and mediators of oxidative injury in infant and adult central nervous system diseases. Curr. Neurovasc. Res. 2004, 1, 341-354. [CrossRef] [PubMed]

36. Miller, E.; Morel, A.; Saso, L.; Saluk, J. Isoprostanes and neuroprostanes as biomarkers of oxidative stress in neurodegenerative diseases. Oxid. Med. Cell Longev. 2014, 2014. [CrossRef] [PubMed]

37. Reich, E.E.; Markesbery, W.R.; Roberts, L.J., 2nd; Swift, L.L.; Morrow, J.D.; Montine, T.J. Brain regional quantification of F-Ring and D-/E-Ring isoprostanes and neuroprostanes in Alzheimer's disease. Am. J. Pathol. 2001, 158, 293-297. [CrossRef]

38. De Felice, C.; Della Ragione, F.; Signorini, C.; Leoncini, S.; Pecorelli, A.; Ciccoli, L.; Scalabrì, F.; Marracino, F.; Madonna, M.; Belmonte, G.; et al. Oxidative brain damage in Mecp2-mutant murine models of Rett syndrome. Neurobiol. Dis. 2014, 68, 66-77. [CrossRef] [PubMed]

39. Fessel, J.P.; Hulette, C.; Powell, S.; Roberts, L.J., 2nd; Zhang, J. Isofurans, but not $\mathrm{F}_{2}$-isoprostanes, are increased in the substantia nigra of patients with Parkinson's disease and with dementia with Lewy body disease. J. Neurochem. 2003, 85, 645-650. [CrossRef] [PubMed]

40. Yen, H.C.; Chen, T.W.; Yang, T.C.; Wei, H.J.; Hsu, J.C.; Lin, C.L. Levels of $\mathrm{F}_{2}$-isoprostanes, $\mathrm{F}_{4}$-neuroprostanes, and total nitrate/nitrite in plasma and cerebrospinal fluid of patients with traumatic brain injury. Free Radic. Res. 2015, 49, 1419-1430. [CrossRef] [PubMed]

41. Nourooz-Zadeh, J.; Liu, E.H.; Yhlen, B.; Anggård, E.E.; Halliwell, B. F4-isoprostanes as specific marker of docosahexaenoic acid peroxidation in Alzheimer's disease. J. Neurochem. 1999, 72, 734-740. [CrossRef] [PubMed]

42. Musiek, E.S.; Cha, J.K.; Yin, H.; Zackert, W.E.; Terry, E.S.; Porter, N.A.; Montine, T.J.; Morrow, J.D. Quantification of F-Ring isoprostane-like compounds ( $\mathrm{F}_{4}$-neuroprostanes) derived from docosahexaenoic acid in vivo in humans by a stable isotope dilution mass spectrometric assay. J. Chromatogr. B Anal. Technol. Biomed. Life Sci. 2004, 799, 95-102. [CrossRef]

43. Grimm, M.O.; Haupenthal, V.J.; Mett, J.; Stahlmann, C.P.; Blümel, T.; Mylonas, N.T.; Endres, K.; Grimm, H.S.; Hartmann, T. Oxidized Docosahexaenoic Acid Species and Lipid Peroxidation Products Increase Amyloidogenic Amyloid Precursor Protein Processing. Neurodegener. Dis. 2016, 16, 44-54. [CrossRef] [PubMed]

44. Halliwell, B. Free radicals and antioxidants: Updating a personal view. Nutr. Rev. 2012, 70, $257-265$. [CrossRef] [PubMed]

45. Mas, E.; Woodman, R.J.; Burke, V.; Puddey, I.B.; Beilin, L.J.; Durand, T.; Mori, T.A. The omega-3 fatty acids EPA and DHA decrease plasma F(2)-isoprostanes: Results from two placebo-controlled interventions. Free Radic. Res. 2010, 44, 983-990. [CrossRef] [PubMed] 
46. Milne, G.L.; Dai, Q.; Roberts, L.J., 2nd. The isoprostane-25 years later. Biochim. Biophys. Acta 2015, 1851, 433-445. [CrossRef] [PubMed]

47. Nourooz-Zadeh, J. Key issues in $\mathrm{F}_{2}$-isoprostane analysis. Biochem. Soc. Trans. 2008, 36, 1060-1065. [CrossRef] [PubMed]

48. Basu, S. Isoprostanes: Novel bioactive products of lipid peroxidation. Free Radic. Res. 2004, 38, 105-122. [CrossRef] [PubMed]

49. Spickett, C.M.; Wiswedel, I.; Siems, W.; Zarkovic, K.; Zarkovic, N. Advances in methods for the determination of biologically relevant lipid peroxidation products. Free Radic. Res. 2010, 44, 1172-1202. [CrossRef] [PubMed]

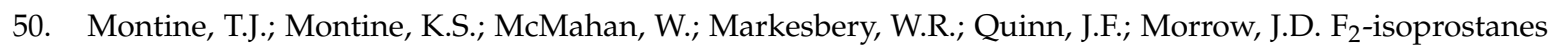
in Alzheimer and other neurodegenerative diseases. Antioxid. Redox Signal. 2005, 7, 269-275. [CrossRef] [PubMed]

51. Halliwell, B.; Lee, C.Y. Using isoprostanes as biomarkers of oxidative stress: Some rarely considered issues. Antioxid. Redox Signal. 2010, 13, 145-156. [CrossRef] [PubMed]

52. Signorini, C.; De Felice, C.; Leoncini, S.; Giardini, A.; D’Esposito, M.; Filosa, S.; Della Ragione, F.; Rossi, M.; Pecorelli, A.; Valacchi, G.; et al. $\mathrm{F}_{4}$-neuroprostanes mediate neurological severity in Rett syndrome. Clin. Chim. Acta 2011, 412, 1399-1406. [CrossRef] [PubMed]

53. Reed, T.T. Lipid peroxidation and neurodegenerative disease. Free Radic. Biol. Med. 2011, 51, $1302-1319$. [CrossRef] [PubMed]

54. Montine, T.J.; Quinn, J.F.; Montine, K.S.; Kaye, J.A.; Breitner, J.C. Quantitative in vivo biomarkers of oxidative damage and their application to the diagnosis and management of Alzheimer's disease. J. Alzheimers Dis. 2005, 8, 359-367. [CrossRef] [PubMed]

55. Greco, A.; Minghetti, L.; Levi, G. Isoprostanes, novel markers of oxidative injury, help understanding the pathogenesis of neurodegenerative diseases. Neurochem. Res. 2000, 25, 1357-1364. [CrossRef] [PubMed]

56. Ehinger, Y.; Matagne, V.; Villard, L.; Roux, J.C. Rett syndrome from bench to bedside: Recent advances. F1000Research 2018, 7, 398. [CrossRef] [PubMed]

57. Signorini, C.; De Felice, C.; Leoncini, S.; Møller, R.S.; Zollo, G.; Buoni, S.; Cortelazzo, A.; Guerranti, R.; Durand, T.; Ciccoli, L.; et al. MECP2 Duplication Syndrome: Evidence of Enhanced Oxidative Stress. A Comparison with Rett Syndrome. PLoS ONE 2016, 11, e0150101. [CrossRef] [PubMed]

58. Leoncini, S.; De Felice, C.; Signorini, C.; Pecorelli, A.; Durand, T.; Valacchi, G.; Ciccoli, L.; Hayek, J. Oxidative stress in Rett syndrome: Natural history, genotype, and variants. Redox Rep. 2011, 16, 145-153. [CrossRef] [PubMed]

59. Signorini, C.; De Felice, C.; Leoncini, S.; Durand, T.; Galano, J.M.; Cortelazzo, A.; Zollo, G.; Guerranti, R.; Gonnelli, S.; Caffarelli, C.; et al. Altered erythrocyte membrane fatty acid profile in typical Rett syndrome: Effects of omega-3 polyunsaturated fatty acid supplementation. Prostagland. Leuk. Essent. Fat. Acids 2014, 91, 183-193. [CrossRef] [PubMed]

60. Chahrour, M.; Zoghbi, H.Y. The story of Rett syndrome: From clinic to neurobiology. Neuron 2007, 56, 422-437. [CrossRef] [PubMed]

61. Percy, A.K.; Lane, J.B. Rett syndrome: Model of neurodevelopmental disorders. J. Child Neurol. 2005, 20, 718-721. [CrossRef] [PubMed]

62. Strimbu, K.; Tavel, J.A. What are biomarkers? Curr. Opin. HIV AIDS 2010, 5, 463-466. [CrossRef] [PubMed]

63. Halliwell, B.; Whiteman, M. Measuring reactive species and oxidative damage in vivo and in cell culture: How should you do it and what do the results mean? Br. J. Pharmacol. 2004, 142, 231-255. [CrossRef] [PubMed]

64. Ciccoli, L.; De Felice, C.; Paccagnini, E.; Leoncini, S.; Pecorelli, A.; Signorini, C.; Belmonte, G.; Guerranti, R.; Cortelazzo, A.; Gentile, M.; et al. Erythrocyte shape abnormalities, membrane oxidative damage, and $\beta$-actin alterations: An unrecognized triad in classical autism. Mediat. Inflamm. 2013, 2013, 432616. [CrossRef] [PubMed]

65. De Felice, C.; Signorini, C.; Durand, T.; Ciccoli, L.; Leoncini, S.; D’Esposito, M.; Filosa, S.; Oger, C.; Guy, A.; Bultel-Poncé, V.; et al. Partial rescue of Rett syndrome by $\omega-3$ polyunsaturated fatty acids (PUFAs) oil. Genes Nutr. 2012, 7, 447-458. [CrossRef] [PubMed]

66. Leung, K.S.; Galano, J.M.; Durand, T.; Lee, J.C. Current development in non-enzymatic lipid peroxidation products, isoprostanoids and isofuranoids, in novel biological samples. Free Radic. Res. 2015, 49, 816-826. [CrossRef] [PubMed] 
67. Taber, D.F.; Morrow, J.D.; Roberts, L.J., 2nd. A nomenclature system for the isoprostanes. Prostaglandins 1997, 53, 63-67. [CrossRef]

68. Roberts, L.J., 2nd; Montine, T.J.; Markesbery, W.R.; Tapper, A.R.; Hardy, P.; Chemtob, S.; Dettbarn, W.D.; Morrow, J.D. Formation of isoprostane-like compounds (neuroprostanes) in vivo from docosahexaenoic acid. J. Biol. Chem. 1998, 273, 13605-13612. [CrossRef] [PubMed]

69. Solberg, R.; Longini, M.; Proietti, F.; Perrone, S.; Felici, C.; Porta, A.; Saugstad, O.D.; Buonocore, G. DHA Reduces Oxidative Stress after Perinatal Asphyxia: A Study in Newborn Piglets. Neonatology 2017, 112, 1-8. [CrossRef] [PubMed]

70. Corcoran, T.B.; Mas, E.; Barden, A.E.; Durand, T.; Galano, J.M.; Roberts, L.J.; Phillips, M.; Ho, K.M.; Mori, T.A. Are isofurans and neuroprostanes increased after subarachnoid hemorrhage and traumatic brain injury? Antioxid. Redox Signal. 2011, 15, 2663-2667. [CrossRef] [PubMed]

(C) 2018 by the authors. Licensee MDPI, Basel, Switzerland. This article is an open access article distributed under the terms and conditions of the Creative Commons Attribution (CC BY) license (http:/ / creativecommons.org/licenses/by/4.0/). 